\title{
ПАРЕМІЇ ЯК ЗАСІБ ПОЛІТИЧНОГО ВПЛИВУ НА АДРЕСАТА В ПУБЛІЦИСТИЧНОМУ ДИСКУРСІ МИХАЙЛА ГРУШЕВСЬКОГО
}

Клімчук Г. П. Паремії як засіб політичного впливу на адресата в публіцистичному дискурсі Михайла Грушевського.

Статтю присвячено дослідженню функціональних особливостей та комунікативно-прагматичного потенціалу прислів 'їв і приказок у публіцистичній спадщині Михайла Грушевського. Здійснено аналіз мовленнєвого впливу узуальних та модифікованих паремій на свідомість реципієнта.

Ключові слова: паремійні одиниці, функціональні особливості, прагматичне значення, індивідуально-авторська трансформація.

Климчук Г. П. Паремии как средство политического воздействия на адресата в публицистическом дискурсе Михаила Грушевского.

Статья посвящена изучению функциональных особенностей и коммуникативнопрагматического потенциала пословиц и поговорок в публицистическом наследии Михаила Грушевского. Выполнен анализ речевого воздействия узуальных и модифицированных паремий на сознание реципиента.

Ключевые слова: паремийные единицы, функциональные особенности, прагматическое значение, индивидуально-авторская трансформация.

Klymchyuk G. P. Paremies as a meams of political impact on an addressee in publicistic discourse of Mihayilo Grushevskyi

The article is devoted to functional features and communicative-pragmatic potential of proverbs and proverbial phrases in the publistical inheritance of Mykhailo Hrushevsky. The analysis of communicative influence and modificated paremies on the consciousness of receptionist is made in the article.

Key words: paremial units, functional peculiarities, pragmatical meaning, individual author's transformation.

Протягом останніх десятиліть у мовознавчих студіях значно посилився інтерес до питання використання мови як засобу маніпуляції та політичного впливу на адресата. У сучасній лінгвістиці ця проблема набуває статусу однієї з найактуальніших. Саме тому об’єктом постійної уваги дослідників виступає публіцистика, яка $є$ потужним джерелом формування колективної громадської думки.

У журналістських статтях органічно переплітаються власне інформативна, регулятивна та афективна функції. Проте досить часто домінуючою виступає саме регулятивна функція, покликана вплинути на свідомість реципієнта, переконати його в необхідності „правильних” з точки зору адресанта дій та оцінок.

Одним із найефективніших засобів мовленнєвого впливу на читача $є$ лінгвоодиниці 3 яскраво вираженою експресивною оцінкою, або т.зв. експресеми. У публіцистичному дискурсі функцію експресем перш за все виконують фразеологізми, зокрема паремії, які несуть у собі інформа- 
цію „не тільки про позначувані ними елементи дійсності, а й про пристосованість семантичного типу їх значень до виконання тієї чи іншої комунікативної ролі, ... а за рахунок прагматичного пласту семантики вони, як правило, свідчать про те чи інше ставлення до позначуваної дійсності того, хто їх використовує" [10, 20-21].

Прагматичний потенціал та когнітивні характеристики прислів “̈в i приказок стали предметом численних лінгвістичних студій у сучасному російському мовознавстві [7; 8]. В україністиці діапазон розвідок, безпосередньо пов'язаних із загальною проблематикою цих усталених висловів теж досить об'ємний. Серед грунтовних праць, присвячених дослідженню паремій як комунікативних одиниць, варто відзначити дисертацію О.Дуденко, де здійснено аналіз номінативної та комунікативної природи українських прислів'їв і приказок [6]. Однак попри наявність чималої кількості наукових робіт в українському мовознавстві комунікативнопрагматичний аспект паремійних виразів усе ще не знаходить належного опрацювання, а особливості функціонування в політичному дискурсі та мовленнєвий вплив цих лінгвоодиниць на адресата взагалі залишаються поза увагою вчених. Тому мета пропонованої розвідки полягає в дослідженні функціонально-прагматичного потенціалу паремій у періодиці Михайла Грушевського, публіцистична діяльність якого була важливим засобом формування національної свідомості та суспільно-політичної думки на Україні в кінці XIX - початку XX століття.

Досягнення мети передбачає розв'язання низки завдань:

- виявити основні функції використання прислів'їв і приказок у політичному дискурсі;

- проаналізувати комунікативно-прагматичні особливості паремійних одиниць у структурі публіцистичних текстів Михайла Грушевського;

- описати прийоми оказіональної трансформації аналізованих народних висловів у суспільно-політичних статтях видатного діяча та визначити їх мовленнєвий вплив на реципієнта.

3-поміж різних стереотипів народно-розмовного джерела паремійні одиниці, що за своєю природою є стійкими, влучними та образними словесними формулами, особливо затребувані в тканині публіцистичних текстів. Вони акумулюють у собі багатовіковий досвід, життєву мудрість, звичаї й традиції того чи іншого народу та передаються з покоління в покоління як невід’ємний компонент духовної культури відповідної мовної спільноти. Народність, загальновживаність, авторитетність цих висловів забезпечує співпадання когнітивних баз учасників комунікації й унеможливлює в процесі обміну інформацією хибне інтерпретування адресатом авторського повідомлення. Такі релевантні ознаки паремій дають підстави мовознавцям кваліфікувати їх як прецедентні висловлювання, які ,зберігають у собі ,мінімізовані” знання й уявлення тієї чи іншої мовної спільноти та формують іiі когнітивну базу" [8, 22-23]. Саме прецедентність виступає голов- 
ним атрибутом прагматичної й функціональної продуктивності паремійних одиниць у канві журналістських публікацій.

Твердження про потужний комунікативно-прагматичний потенціал прислів “їв і приказок у сучасній лінгвістичній практиці $є$ аксіоматичним. Так, відома дослідниця теорії мовленнєвого впливу А.Кисельова на підставі чітко вираженої (імпліцитно чи експліцитно) регуляційно-спонукальної орієнтації паремій пропонує диференціювати їх як спонукальні прагмеми. У запропонованій ученою прагмалінгвістичній класифікації мовних одиниць аналізованим висловам відводиться одне з центральних місць, позаяк „узагальнюючи життєвий досвід народу, вони містять рекомендації соціальної та індивідуальної поведінки в тих чи інших життєвих ситуаціях" [7, 108].

У публіцистичному доробку Михайла Грушевського прислів'я та приказки - важливий текстотворчий і соціально-оцінний компонент, а також дієвий засіб впливу на читача. Здебільшого вони мають народно-розмовне забарвлення й використовуються автором як засіб увиразнення стандартного інформативного тексту. Наприклад: I громадянство се міuно трималося принцину, ,ліпше своє латане, як чуже хапане” $i$ з усієї сили старалося підтримати свої видавництва ..., хоч як скромно або убого вони виглядали в порівнянні з тодішнім розцвітом офіціальної й неофіціальної російської культури [3, 79] $]^{1}$; Так відганяють людей, охочих попрацюювати для народу, а потім даремно пробують канцелярськими способами, через чиновників налагодити діло, яке потребує щзирих робітників на місиі, на селах - таких, щуоб працювали б з любові до діла, до народу, „для Iсуса, а не для хліба куса", як у нас говорять [4, 248]. 3 наведених комунікативнопрагматичних ситуацій видно, що паремійні вирази значно пожвавлюють, лаконізують і логізують розповідь адресанта, роблять іiі експресивною й переконливою.

Спостереження над мовним матеріалом доводить, що Михайло Грушевський послуговується прислів'ями та приказками, як правило, з метою підкреслення основної думки повідомлення. Стислі за складом і місткі за змістом вони унаочнюють шаблонну інформацію, допомагають підкріпити ii афористичним народним виразом. Розміщуючи ї наприкінці абзацу (Просимо пам'ятати, щзо кожне збільщення передплати ... піде не до кишень видавців, а на збільшення й поліпшення самих видань, і Украӥна буде мати часописи такі, які б стояли і змістом і обсягом на рівні з найліпиими чужими виданнями, тільки тоді, як сього захоче саме громадянство, сам передплатник. „Прибудь щастя, розум буде” [4, 10]), окремого структурного підрозділу (Але щзо ж, кон'юнктура нинішнього дня отверзла слухи для сього всього, і пустобрехи брешуть далі, чуючи, щзо сьогодні їх день i треба спішитися - „коваль клепле, поки тепле” [3, 139]), або й усієї пу-

${ }^{1}$ Тут і далі правопис автора наближено до сучасних літературних норм зі збереженням усіх лексичних форм і мовно-стилістичних особливостей оригіналу. 
блікації (Бо щзо воно таки до того прийде, щзо жінкам буде у всім рівне право, то певно. Не тепер, то в четвер [4, 252]), автор значно увиразнює нейтральний контекст, посилює його емоційність і тим самим забезпечує переконливе та образне узагальнення попереднього висловлювання.

Паремійні одиниці не тільки резюмують логічну аргументацію мовця, але й, поставлені на початок надфразної єдності, виступають своєрідними ,зачинами”, змушуючи читача порівнювати відповідність наступного контексту з їх змістом. Наприклад: „До булави треба голови”! Коли суспільність наша бачить, щео ї̈ провідники уважають можливим зробити з такої справи, як розбудова руського театру у Львові, альфу і омегу національної роботи, ... то та оплакана ,розтіч” стає, може, якраз першим симптомом, щзо суспільність починає отямлюватися й орієнтуватися в ситуаціï [2, 269]; На мертвого собаки не брешуть. Видко, чується в українтві сила, рух, життя, коли страшаться ним чи сподіваються пострашити кого треба для одержання „знаків (мабуть, монетних), установлених за спасение погибающего в волнах" російського отечества $[3,44]$. Як видно з контекстів, розміщені на початку висловлювання, народні вирази вносять у політичний дискурс яскраво виражену емоційну оцінність та експресивність, завдяки чому істотно привертають увагу адресата, зацікавлюють його до подальшого прочитання твору.

Грунтовний аналіз ілюстративного матеріалу засвідчує, що введення у мовну тканину статей Михайла Грушевського прислів’їв і приказок підпорядковується визначальній меті публіцистики, яка полягає в здійсненні впливу на читача та досягається завдяки реалізації пареміями в політичному дискурсі таких комунікативно-прагматичних завдань:

- формулювання прямої чи зумовленої закономірності перебігу певних суспільно-політичних подій, явищ соціального буття: $B$ нім (великім землеволодінні - Г.К.) можуть бути одиниці, неповинні в антинародній політиці, навіть симпатичні нам, але в великім вогні суспільних і національних переворотів з сухим деревом горить і мокре [2, 367]; Противно, всі дороги ведуть до Рима, по старому прислів'ю, $і$ всяка робота в якійнебудь сфері ... дасть певний прибуток і в зрості тої загальної національної самосвідомості $[3,8]$; Але й сим разом надії не справдилися, а вийшло більше на старе прислів'я: „Привикне за возом бігати, побіжнть $і$ за саньми" [3, 273]; Треба пам'ятати про те, щуо яка б ніч темна не була, а наступить ранок... [4, 282];

- висловлення рекомендацій, порад, настанов, підказаних історичним досвідом, тим чи іншим фактом 3 народного життя. Прикметно, що публіцист, звертаючись до реципієнта, уникає паремій, семантична структура яких містить явно виражені експліцитні повчання. Більшість аналізованих висловів у творах Михайла Грушевського - це рекомендації імпліцитного характеру, що завуальовано спонукають читача до конкретних дій та вчинків. Наприклад: Воно хоч і кажуть, щзо слово - то срібло, а мовчанка - 
золото, однак иче не завсіди буває правда. Недурно і так кажуть: теля не реве - корова не чує. Поки селяни самі про свої потреби не подбають, хто про них подумає? [4, 397];

- вираження соціальної оцінки (як правило, негативної) та авторського ставлення до зображуваних подій: Оскільки не являються вони (поради - Г.К.) продуктом простого лицемірства..., пояснюються вони прислів'ям: „Ситий голодного не розуміє”, а родяться наслідком байдужої рівнодушності й браку заінтересування справою [2, 342]; Се не наші землякиукраӥнці, котрих, як то кажуть, можна $і$ з хлібом їсти й на масло бити, - се поляки $[3,11]$

- створення стилістичного ефекту (підвищення загальної експресивності, емоційності, образності повідомлення тощо): Вже давно апостоли патріотизму Меншиков з Суворіним прицінювалися Привіслянський край продать німиям по четвертній за душу, як за добрих кріпацьких часів ... Не по четвертній, то хоч по десятиі. 3 паршивого козла хоч вовни кусок. Хіба мала й потім щзе всякого інородчя лишиться? [3, 155]; А від пруссаків тільки всього тої помочі, щуо туди йдуть люди з Галичини на заробітки кривавицею „пруські марки” заробляють. Але брехуни брешуть; кажуть: брехати - не ціпом махати [4, 402].

Варто відзначити, що суспільно-політична спадщина Михайла Грушевського не обмежується лише узуальним відтворенням прислів”ї та приказок. Широкий діапазон мовленнєвого впливу на адресата в публікаціях автора мають структурно-семантичні модифікації усталених народних висловів, функціонально-прагматичне навантаження яких повноцінно й ефективно можна визначити тільки в межах контексту.

У мовознавчій літературі під трансформацією фразеологічних, зокрема й паремійних, зворотів прийнято вважати „видозміну структури стійких сполучень слів, яка спричиняє зрушення в їхній семантиці, унаслідок чого узуальна форма стійких словосполук протиставляється їхній оказіональній формі" $[9,6]$. Процес сприйняття та усвідомлення невідповідності між творчо переосмисленим варіантом та його традиційним відповідником вимагає від реципієнта більшого зосередження уваги, фонових знань та „чуття” мови, однак подальше ,розпізнавання" в оказіональному виразі звичного народного прислів'я чи приказки емоційно „,компенсує” інтелектуальні потуги читача й значно підвищує експресивність авторського повідомлення. Залучення в структуру журналістських статей відповідних одиниць, як правило, спрямоване на привернення уваги адресата, стимулювання його до прочитання певної інформації, підсилення аргументації та створення різноманітних стилістичних ефектів.

Детальне дослідження мови публіцистики відомого суспільнополітичного діяча дає підстави виокремити такі різновиди модифікації й контекстуальної інтерпретації паремій як алюзія, редукція та поширення компонентного складу. 
Основним прийомом структурно-семантичної трансформації прислів'їв і приказок у політичному дискурсі Михайла Грушевського є натяк (алюзія). Суть відповідного різновиду полягає в тому, що самого „фразеологічного звороту як цілісної мовної одиниці тут, власне, вже немає, проте для правильного розуміння контексту і сприйняття його естетичних якостей необхідно знати і мати на увазі фразеологізм як такий, тобто у такому вигляді, у якому він уживається в мовній системі" $[11,143]$. Iнакше кажучи, тут ми маємо справу з одним, кількома або й усіма словамипрототипами традиційного народного вислову, що вводяться в текст за зразком вільного словосполучення та, виконуючи функцію своєрідного натяку, наштовхують реципієнта на сприйняття традиційного усталеного виразу. Для розпізнання й адекватного сприйняття алюзивно наявної в тексті паремії, як правило, необхідне залучення фонових відомостей і широкого контексту. Наприклад: Тим часом все-таки, хоч в невідповідних обставинах вибрана, нинішня Дума наша несогірша, і не тільки кадети, а й люди з багатьох інших партій не мають великої охоти міняти нинішню синицю на будучого журавля [2, 363]; Коли суспільність вважає, що такі вироби, як „Історія” д. Аркаса, сповняє завдання популярної історії як не можна ліпше; коли праві депутати ї̈ хвалять, книгоноші плачуть, публіцисти благовіствують славу ї̈ й блаженні люди їм вірять - „освіченим кругам”, очевидно, зістається тихо сидіти. Сучасний украӥнський Сенька, значить, знайшов свою шапку й може штатувати в ній, скільки йому завгодно [3, 90]. Наведені комунікативні ситуації підтверджують той факт, що алюзія на відомі читачеві прислів'я значно посилює авторську аргументацію та переконливість публіцистичного твору. Своєю незвичною формою натяк викликає підвищену реакцію реципієнта й допомагає адресанту досягти бажаного прагматичного ефекту.

Одним із різновидів контекстуального переосмислення паремійних одиниць у суспільно-політичних статтях Михайла Грушевського є скорочення (редукція) їх компонентного складу. У лінгвістиці під редукцією прийнято вважати „звуження рамок фразеологізму, усічення окремих його компонентів, зумовлене прагненням до економії мовних засобів і лаконізації мовлення, до усунення надлишкових з точки зору конкретного факту комунікації компонентів" $[1,130]$.

У творах публіциста прислів'я і приказки не часто піддаються редукції, проте, незважаючи на функціональне обмеження, вони істотно стимулюють емоційне сприйняття тексту, допомагають адресантові загострити та оживити народний вислів без зміни його значення й тим самим досягти бажаного ефекту. Наприклад: Царство свободи здобувається також сильним примусом над собою, як і изарство Боже, обічяне колись вірним християнам. Менше всього годиться для вступу до нього моральний чи політичний індиферентизм, принции, ,моя хата з краю...” [5, 230]. Як видно 3 контексту, редукований варіант прислів'я моя хата з краю, я нічого не 
знаю виконує функцію лаконізації, логізації та оцінки викладу повідомлення, у якому автор не приховує гіркої іронії й незадоволення національною байдужістю українців. Усічення народного виразу спонукає читачів до власних роздумів і висновків.

Суть прийому поширення складу паремійних одиниць полягає в уведенні до їх структури слів вільного вжитку, які конкретизують значення узуального усталеного вислову та наближають його до конкретної мовленнєвої ситуації. У публіцистичних творах Михайла Грушевського нами зафіксовано випадки інтерпозитивного розширення структури прислів'я чи приказки оказіональними компонентами, вибір яких зумовлений відповідним контекстом, як-от: Все зісталося на місиі, вся та убога зверхня декорачія, котра має посвідчити ,,перед світом”, щзо $i$,ми люди”, $i$ все $y$ нас по-людськи - єсть у нас і органи щзоденні (загальне число: один), i органи літературно-наукові (так само один)... - всякої тварі бодай по штучі, коли не по парі, коли Господь Бог на більше не позволяе ... [3, 183]. Наведений приклад засвідчує, що поширювачі не тільки істотно уточнюють і конкретизують значення узуальної паремії, але й змушують читача взяти під сумнів узагальнені в ній життєві істини, відтак змінюють семантику цієї лінгвоодиниці та посилюють емоційно-експресивне навантаження висловлення.

Отже, своєрідна манера індивідуально-авторського переосмислення та творчої модифікації прислів 'їв і приказок робить публіцистику Михайла Грушевського могутнім засобом впливу та формування громадської думки.

Як свідчить аналіз ілюстративного матеріалу, у мовній тканині політичного дискурсу паремії відзначаються високою функціональнопрагматичною продуктивністю. Крім притаманних їм номінативної, аксіологічної та текстотворчої функцій, ці лінгвоодиниці виступають своєрідними активізаторами уваги реципієнта. Активне звернення Михайла Грушевського до прислів 'ів і приказок, на наш погляд, продиктоване бажанням переконати читача, вплинути на його свідомість, аргументувати висловлену думку та підпорядковується загальним комунікативно-прагматичним завданням публіцистичного стилю.

\section{Література}

1. Білоноженко В. М. Функціонування та лексикографічна розробка українських фразеологізмів / Білоноженко В. М., Гнатюк І. С. - К. : Наукова думка, 1989. $-156 \mathrm{c}$.

2. Грушевський М. С. Твори: У 50-и т. / [редкол.: Сохань П., Дашкевич Я., Гирич I. та ін.]; за ред. П. Сохань. - Львів : Світ, 2002. - Т. 1: Серія „Суспільнополітичні твори (1894-1907)". - 592 с.

3. Грушевський М. С. Твори: У 50-и т. / [редкол.: Сохань П., Дашкевич Я., Гирич І. та ін.]; за ред. П. Сохань. - Львів : Світ, 2005. - Т. 2: Серія „Суспільнополітичні твори (1907-1914)”. - 704 с. 
4. Грушевський М. С. Твори: У 50-и т. / [редкол.: Сохань П., Дашкевич Я., Гирич I. та ін.]; за ред. П. Сохань. - Львів : Світ, 2005. - Т. 3: Серія „Суспільнополітичні твори (1907- березень 1917)". - 792 с.

5. Грушевський М. С. Твори: У 50-и т. / [редкол.: Сохань П., Дашкевич Я., Гирич I. та ін.]; за ред. П. Сохань. - Львів : Світ, 2007. - Т. 4. Кн. I: Серія „Суспільно-політичні твори (доба Української Центральної Ради березень 1917 - квітень 1918)". - 432 с.

6. Дуденко О. В. Номінативна та комунікативна природа українських паремій: автореф. дис. на здобуття наук. ступеня канд. філол. наук : спец. 10.02.01 „Українська мова ” / Дуденко Олена Володимирівна. - Київ, 2002. - 24 с.

7. Киселева Л. А. Вопросы речевого воздействия / Л. А. Киселева. - Л. : Изд-во Ленинградского у-та, 1978. - 160 с.

8. Константинова А. А. Коммуникативно-прагматический потенциал пословиц и поговорок в современной англо-американской прессе: автореф. дис. на соискание учен. степени канд. филол. наук : спец. 10.02.04 „Германские языки” / Константинова Анна Александрова. - М., 2007. - 24 с.

9. Кочукова Н. І. Експресивно-виражальні можливості трансформованих стійких сполучень слів (на матеріалі української преси кінця XX - початку XXI століття) : автореф. дис. на здобуття наук. ступеня канд. філол. наук : спец. 10.02.01 „Українська мова” / Кочукова Наталія Іванівна. - Київ, 2004. - 19 с.

10. Телия В. Н. Типы языковых значений: связанное значение слова в языке / В. Н. Телия. - М. : Наука, 1981. - 269 с.

11. Шанский Н. М. Фразеология современного русского языка: [учебное пособие для вузов]. - М. : Высшая школа, 1963. - 155 с. 